\title{
PENERAPAN METODE PEMBELAJARAN SQ3R (SURVEY, QUESTION, READ, RECITE, REVIEW) UNTUK MENINGKATKAN HASIL BELAJAR BIOLOGI MATERI SISTEM PENCERNAAN MAKANAN KELAS XI SMA MUHAMMADIYAH AIMAS
}

\section{ANANG TRIYOSO}

SMA Muhammadiyah Aimas

\begin{abstract}
ABSTRAK
Penelitian ini bertujuan: 1) Untuk mengetahui penerapan metode pembelajaran SQ3R terhadap hasil belajar biologi siswa kelas XI di SMA Muhammadiyah Aimas. 2) Untuk mengetahui hambatan penerapan metode pembelajaran SQ3R terhadap hasil belajar biologi di SMA Muhammadiyah Aimas. Penelitian ini merupakan penelitian tindakan kelas (Classroom Action Research) yang dilaksanakan dalam 2 siklus. Subyek penelitian adalah siswa kelas XI SMA Muhammadiyah Aimas pada semester genap tahun pelajaran 2017/2018 dengan jumlah siswa sebanyak 23 orang. Prosedur penelitian terdiri dari 4 tahap di setiap siklusnya, yakni perencanaan, pelaksanaan tindakan, observasi dan refleksi. Indikator hasil belajar pada penelitian ini berupa tercapainya ketuntasan belajar secara individual maupun klasikal. Pengumpulan datanya dilakukan dengan metode: wawancara, observasi, dokumentasi, diskusi dan tes evaluasi. Data hasil pengamatan nilai diskusi dan nilai evaluasi diolah dengan analisis deskriptif untuk menggambarkan keadaan peningkatan pencapaian keberhasilan tiap siklus. Hasil penelitian menunjukkan bahwa: 1) Hasil belajar biologi siswa melalui penerapan metode pembelajaran SQ3R mengalami peningkatan, khususnya pada materi pokok sistem pencernaan makanan. Pada siklus I diperoleh nilai diskusi individu < KKM sebanyak 5 siswa, sedangkan $>$ KKM 18 siswa dengan rata-rata 62,23 dan ketuntasan belajar 78,26\% meningkat menjadi 75,72 dengan ketuntasan belajar 91,3\% pada siklus II yaitu < KKM sebanyak 2 siswa sedangkan > KKM 21 siswa. Serta nilai evaluasi dengan rata-rata $\mathbf{6 6 , 2 2}$ dengan ketuntasan belajar 78,26\% dan meningkat menjadi 76,26 dengan ketuntasan belajar 95,65\% pada siklus II. Sehingga bisa disimpulkan bahwa terjadi peningkatan nilai rata-rata dari siklus I ke siklus II dan tidak perlu dilakukan siklus ke III. 2) Hambatan pengunaan metode SQ3R yaitu sikap pasif siswa serta bergantung pada orang lain dalam proses pembelajaran dan keterbatasan fasilitas pembelajaran seperti sumber belajar dan alat peraga pembelajaran yang tersedia.
\end{abstract}

Kata kunci: SQ3R, survey, question, read, recite, review, pencernaan, makanan

ABSTRACT
This study aims: 1) To find out the application of the SQ3R learning method to the biology class XI student learning outcomes at Muhammadiyah Aimas High School. 2) To find out the obstacles in applying the SQ3R learning method to biology learning outcomes at Muhammadiyah Aimas High School. This research is a Classroom Action Research conducted in 2 cycles. The research subjects were students of class XI Muhammadiyah Aimas High School in the even semester of the academic year 2017/2018 with a total of 23 students. The research procedure consisted of 4 stages in each cycle, namely planning, implementing actions, observing and reflecting. Indicators of learning outcomes in this study include the achievement of individual and classical learning completeness. The data collection is done by methods: interviews, observation, documentation, discussion and evaluation tests. Data from observations of discussion values and evaluation values are processed with descriptive analysis to illustrate the increasing state of success in each cycle. The results showed that: 1) Student biology learning outcomes through the application of SQ3R learning methods have increased, especially in the subject matter of the digestive system of food. In the first cycle the individual discussion scores <KKM obtained by 5 students, while> KKM 18 students with an average of 62.23 and mastery learning $78.26 \%$ increased to 75.72 with mastery learning $91.3 \%$ in the second cycle namely $<K K M$ as many as 2 students while > KKM 21 students. And the evaluation value with an average of 66.22 with $78.26 \%$ mastery learning and increased to 76.26 with $95.65 \%$ mastery learning in the second cycle. So it can be concluded that an increase in the average value from cycle I to cycle II does not need to be done to cycle III. 2) Barriers to the use of the SQ3R method are the passive attitude of students and depend on others in the learning process and the limitations of learning facilities such as learning resources and learning aids that are available.

Keywords: SQ3R, survey, question, read, recite, review, digestion, food

\section{PENDAHULUAN}

Belajar merupakan tindakan dan perilaku siswa yang komplek. Sebagai tindakan, maka belajar hanya dialami siswa itu sendiri. Siswa adalah penentu terjadi atau tidaknya proses belajar. Proses belajar terjadi berkat siswa memperoleh sesuatu yang ada di lingkungan sekitar, yang berupa alam, benda-benda, hewan, tumbuh-tumbuhan, manusia maupun hal-hal 
yang dijadikan bahan belajar (Dimyati \& Mujdiono, 2006). Selain itu perlu adanya interaksi antara guru dan siswa. Sedangkan interaksi terjadi saat guru mengajar di kelas. Dimyati dan Mudjiono menyatakan bahwa dalam teori kognitif belajar menunjukkan adanya jiwa yang aktif, jiwa mengolah informasi yang kita terima, tidak sekedar menyimpannya saja tanpa mengadakan transformasi (Dimyati \& Mujdiono, 2006). Hal ini sesuai dengan salah satu prinsip belajar adalah keaktifan. Dengan demikian, belajar hanya dapat terjadi apabila siswa aktif mengalami sendiri. Dalam mewujudkan peserta didik aktif maka perlu adanya aktivitas belajar. Aktivitas belajar ini dapat terwujud jika siswa dihadapkan pada masalah.

Berhasil atau gagalnya pencapaian tujuan pendidikan tergantung pada proses belajar mengajar yang dialami siswa dan guru. Hilgard dan Marquis berpendapat bahwa belajar merupakan proses mencari ilmu yang terjadi dalam diri seseorang melalui latihan dan pembelajaran sehingga terjadi perubahan dalam diri sendiri (Sagala, 2003). Untuk itu guru perlu meningkatkan mutu pembelajarannya, dimulai rancangan pembelajaran yang baik dengan memperhatikan tujuan, karakteristik siswa, materi yang diajarkan, dan sumber belajar yang tersedia. Kenyataannya masih banyak ditemui proses pembelajaran yang kurang berkualitas, tidak efisien dan kurang mempunyai daya tarik, bahkan cenderung membosankan, sehingga hasil belajar yang dicapai tidak optimal.

Proses pembelajaran yang baik adalah pengajaran yang menyediakan dan memberi kesempatan pada siswa untuk mengembangkan otak kiri (otak perekam) dan otak kanan (otak pemikir). Siswa tidak hanya tahu tentang "sesuatu" tetapi juga dapat bertanya tentang sesuatu, dapat menyampaikan sesuatu, dan dapat memperagakan sesuatu (Harsanto, 2007). Salah satu proses pembelajaran dengan menggunakan otak kanan/otak berfikir adalah mengkritisi apa yang dibaca serta mampu menerangkan apa yang dibaca kepada orang lain dengan kata-katanya sendiri.

Siswa hanya mungkin dapat belajar dengan baik manakala ada dalam suasana yang menyenangkan, merasa aman, bebas dari rasa takut (Sanjaya, 2009). Oleh karena itu guru harus bisa menciptakan iklim belajar yang kondusif karena merupakan faktor pendorong yang dapat memberikan daya tarik tersendiri dalam proses belajar, sebaliknya iklim yang kurang menyenangkan akan menimbulkan kejenuhan dan rasa bosan. Iklim belajar yang menyenangkan akan membangkitkan semangat dan menumbuhkan aktivitas serta kreativitas siswa, siswa lebih mudah dalam memahami materi pelajaran.

Metode adalah salah satu alat untuk mencapai tujuan. Dengan memanfaatkan metode secara tepat guru akan mampu mencapai tujuan pengajaran (Djamarah dan Zain, 2006). Dalam menggunakan suatu metode pembelajaran, tidak ada suatu metode yang lebih baik dari metode pembelajaran yang lain.
Masing-masing metode pembelajaran mempunyai keunggulan dan kelemahan, oleh karena itu guru harus bisa memilih metode pembelajaran sesuai dengan materi yang disampaikan.

Aktivitas guru dan siswa sebagai pelaku utama dalam kegiatan belajar mengajar mutlak diperlukan demi tercapainya tujuan belajar. Aktivitas guru yang mampu membangkitkan aktivitas dan kreatifitas siswa, sehingga kegiatan belajar mengajar berlangsung dinamis. Siswa yang aktif mendengar, berfikir, bertanya, menjawab, menanggapi pertanyaan adalah salah satu bukti keberhasilan dalam proses belajar mengajar.

Kerja sama dalam kelompok dapat dikaitkan dengan nilai, sehingga kerja sama siswa makin intensif dan siswa dapat mencapai kompetensinya. Belajar bersama dalam kelompok adalah suatu cara yang dipakai untuk menyelenggarakan pembelajaran dalam bentuk kelompok belajar yang lebih kecil (Harsanto, 2007). Peserta didik dalam satu kelas dibagi menjadi beberapa kelompok belajar yang lebih kecil yang heterogen (campuran) dalam hal kemampuan intelektual, jenis kelamin, dan latar belakang budaya, sehingga terwujud kerjasama untuk saling membantu dalam memahami materi. Dipandang dari tingkat partisipasi aktif siswa, keuntungan belajar bersama secara kelompok mempunyai tingkat partisipasi aktif yang tinggi.

Supaya memperoleh hasil belajar yang berkualitas, harus dirancang proses pembelajaran yang berkualitas dengan memperhatikan tingkat berpikir yang akan dipelajari dan dilatihkan. Rancangan proses pembelajaran yang baik adalah rancangan pembelajaran yang menggunakan indikator belajar sebagai rambu-rambu dalam pencapaian hasil (Harsanto, 2007). Indikator yang dirumuskan sacara baik dapat digunakan untuk mendeteksi sejauh mana hasil belajar dapat dicapai.

Mengalami langsung apa yang sedang dipelajari akan mengaktifkan lebih banyak indera daripada hanya mendengarkan guru menerangkan. Hal ini menunjukkan bahwa jika mengajar dengan banyak berceramah, maka tingkat pemahaman siswa hanya $20 \%$, tetapi jika siswa diminta untuk melakukan sesuatu sambil mengkomunikasikan, tingkat pemahaman peserta didik dapat mencapai sekitar 90\% (Yamin dan Maisah, 2009). Pada dasarnya semua anak memiliki potensi untuk mencapai kompetensi sehingga perlu adanya kreatifitas guru untuk membantu mencapainya.

Untuk itu penulis menerapkan metode pembelajaran SQ3R. Metode belajar tersebut adalah cara mempelajari teks (bacaan) kususnya yang terdapat dalam buku, artiket ilmiah, dan laporan penelitian. Siswa akan mudah mengingat materi, karena siswa belajar secara berkelompok dan diberi kesempatan lebih aktif mencari serta memahami materi dari teks atau buku sehingga terdapat peluang lebih besar untuk meningkatkan hasil belajar biologi pada materi pokok sistem pencernaan makanan. 
Dari uraian di atas maka penulis berkeinginan mengadakan suatu penelitian tindakan kelas dengan judul "Penerapan metode pembelajaran SQ3R (survey, question, read, recite, review ) untuk meningkatkan hasil belajar biologi materi sistem pencernaan makanan kelas XI SMA Muhammadiyah Aimas”. Tujuan yang hendak dicapai dalam penelitian ini adalah sebagai berikut: 1. Untuk mengetahui penggunaan metode pembelajaran SQ3R terhadap hasil belajar biologi siswa di SMA Muhammadiyah Aimas materi pokok sistem pencernaan makanan. 2 . Untuk mengetahui hambatan penggunaan metode Pembelajaran SQ3R terhadap hasil biologi di SMA Muhammadiyah Aimas.

\section{METODE PENELITIAN}

Subyek penelitian ini adalah siswa kelas XI SMA Muhammadiyah Aimas dengan jumlah siswa 23 orang dengan komposisi 12 anak laki-laki dan 11 anak perempuan.

Penelitian ini dilaksanakan pada semester genap tahun ajaran 2017/2018 siswa kelas XI SMA Muhammadiyah Aimas. Penulis akan menggunakan waktu penelitian selama 2 bulan yaitu minggu ke dua bulan Januari $2018 \mathrm{~s} / \mathrm{d}$ minggu ke empat bulan Februari 2018. Waktu penelitian ini terhitung mulai peneliti melakukan observasi dan meminta izin ke pihak sekolah hingga selesainya proses penelitian tindakan kelas dan permohonan surat pengesahan penelitian.

Dasar untuk tercapainya suatu penelitian, maka diperlukan data yang mempunyai validitas yang tinggi. Dalam penelitian ini penulis menggunakan beberapa metode yaitu: Metode Dokumentasi, Metode Wawancara, Metode Observasi dan Metode Tes

Metode penelitian yang penulis gunakan dalam penelitian ini adalah Penelitian Tindakan Kelas (PTK). Menurut Zainal Aqib, Penelitian Tindakan Kelas adalah suatu penelitian yang dilakukan oleh guru dikelasnya sendiri melalui refleksi diri dengan tujuan untuk memperbaiki kinerjanya sehingga hasil belajar siswa meningkat (Aqib, dkk, 2008). Penelitian tindakan ini dilaksanakan selama dua siklus yaitu siklus I dan siklus II.

Model penelitian tindakan yang dilakukan dalam penelitian ini adalah model spiral dari Kemmis dan Taggart (2010) yang terdiri dari beberapa siklus tindakan. Dimana setiap siklus tersebut terdiri 4 tahapan yang meliputi perencanaan, pelaksanaan tindakan, observasi dan refleksi.

Data hasil pengamatan dan tes diolah dengan analisis deskriptif untuk menggambarkan keadaan peningkatan pencapaian keberhasilan tiap siklus dan untuk menggambarkan keberhasilan pembelajaran dengan metode pembelajaran SQ3R (Survey, Question, Read, Recite, Review) yang dapat meningkatkan hasil belajar siswa.

Sebagai indikator keberhasilan dari penelitian tindakan kelas ini adalah jika $85 \%$ siswa telah memperoleh nilai minimal 62 (sesuai ketentuan KKM dari sekolah). Seorang siswa dikatakan telah mencapai ketuntasan belajar secara individu apabila siswa tersebut telah mencapai ketentuan belajar secara individual dan mendapat nilai $\geq 62$ (sesuai ketentuan dari sekolah).

\section{PEMBAHASAN}

Penelitian tindakan kelas ini dilakukan di SMA Muhammadiyah Aimas kelas XI IPA yang dilaksanakan dalam dua siklus, setiap siklus terdiri dari tahap perencanaan, pelaksanaan tindakan, observasi dan refleksi.

1. Siklus I

a. Perencanaan

Pada tahap perencanaan ini, peneliti mempersiapkan segala sesuatu yang diperlukan selama proses penelitian berlangsung, diantaranya yaitu:

1) Membuat Daftar nama siswa (untuk absensi dan penilaian)

2) Menyusun Rencana Pelaksanaan Pembelajaran (RPP).

3) Membuat Pertanyaan diskusi kelompok serta lembar penilaian diskusi

4) Menyiapkan buku paket.

5) Membuat Soal Evaluasi dan kunci jawabannya, untuk siklus I.

b. Pelaksanaan tindakan

Pembelajaran dengan menggunakan metode SQ3R dicirikan dengan ketelitian siswa dalam memahami sebuah teks bacaan dan mampu mengambil intisari yang dimaksud, untuk mempermudah pemahaman siswa dikarenakan bahan materi yang banyak, maka dibentuk kelompok belajar untuk berdiskusi kecil dalam kelompok serta menjawab pertanyaan yang sudah disediakan peneliti.

Siklus I dilaksanakan dua pertemuan empat jam pelajaran yaitu pada tanggal 10 Januari 2018 dan tanggal 13 Januari 2018.

1) Pertemuan pertama (penjelasan materi, pembentukan kelompok \& pelaksanaan survey, read, question)

Awal pertemuan guru menjelaskan manfaat makanan dan gambaran umum tentang zat-zat makanan. Pembagian kelompok dilakukan secara acak dengan harapan kerjasama sesama siswa dalam kelompok dapat terbentuk, tetapi karena pembentukan acak tanpa melihat tingkat kecerdasan terdapat satu kelompok lebih ungul dari kelompok lain dilihat dari presentasi dan tugas rangkuman yang sudah dikerjakan serta hasil evaluasi siklus I. Materi tiap kelompok berbeda, kelompok 1 membahas karbohidrat, kelompok 2 lemak, kelompok 3 protein, kelompok 4 vitamin, dan kelompok 5 mineral dan air.

Untuk menentukan giliran presentasi didepan kelas tiap ketua kelompok maju mengambil nomor undian. Urutan presentasi pada siklus I yaitu kelompok 3 (protein), kelompok 2 (lemak), 
kelompok 5 (mineral dan air), kelompok 1 (karbohidrat), dan kelompok 4 (vitamin).

Sedangkan langkah yang harus dilakukan siswa dalam proses pembelajaran adalah mencari atau survey bahan/sumber belajar dengan harapan siswa lebih kreatif tetapi karena metode pembelajaran yang digunakan termasuk baru bagi siswa, maka mereka mengalami kesulitan sehingga peneliti dan guru membantu dengan membagikan buku paket. Langkah selanjutnya adalah pertanyaan (question) dan membaca (read). Siswa membaca serta menjawab pertanyaan yang sudah disediakan peneliti, untuk membantu siswa memfokuskan materi yang harus dikuasai karena berbentuk kelompok, siswa melakukan diskusi kecil serta menyatukan ide dari berbagai buku yang dipegang.

2) Pertemuan kedua (pelaksanaan recite \& review)

Pada pelaksanaan recite dan review lebih ditekankan dalam bentuk presentasi karena penguasaan siswa akan jelas terlihat ketika mampu menjelaskan kepada orang lain dan mampu menjawab pertanyaan yang diajukan dari teman dalam kelompok lain.

Dalam siklus I juga masih banyak terdapat siswa yang bergantung dengan teman satu kelompoknya untuk menyelesaikan tugas atau dapat dikatakan rasa tanggung jawab diri sendiri masih kurang. Terbukti dalam diskusi kelompok kecil maupun presentasi kelompok didepan kelas masih didominasi satu, dua anak yang tergolong pandai sedangkan siswa yang lain terlihat lebih pasif. Bahkan dalam pertemuan pertama masih terdapat kegaduhan dari beberapa siswa sehingga waktu untuk diskusi kelompok kecil menjadi molor dari waktu yang ditentukan yaitu 1 kelompok 25 menit .

Dalam presentasi kelompok didepan kelas belum ada kerjasama antar anggota, pengelolaan waktu dari moderator juga belum ada, serta pembatasan masalah atau materi belum terlaksana sehingga presentasi melebar sampai membahas sekilas tentang organ pencernaan pada manusia. Kemudian guru mencoba menengahi dan mengembalikan pada pembahasan materi yaitu zat-zat makanan.

\section{c. Observasi dan evaluasi}

Data peningkatan siswa pada pembelajaran biologi dengan menggunakan metode pembelajaran SQ3R, diamati langsung pada saat pelaksanaan tindakan. Peneliti mengamati pelaksanaan pembelajaran yang disajikan oleh guru mata pelajaran dan pada saat siswa mengerjakan soal diskusi kelompok. Guru dan peneliti berkeliling mengamati aktifitas, komunikai dan kerja sama sesama siswa dalam menyelesaikan langkah-langkah SQ3R.

Hasil belajar siklus I terlihat dari nilai diskusi dan nilai evaluasi. Pada saat pelaksanaan pembelajaran mengunakan metode SQ3R sekaligus dilakukan penilaian diskusi oleh guru dan peneliti ada tiga siswa yang tidak hadir sehingga nilainya nol. Penilaian diskusi untuk kelompok berdasarkan penguasaan materi yang dipresentasikan, pengelolaan waktu dalam presentasi, pembuatan rangkuman materi sebagai bahan presentasi serta menjawab pertanyaan yang diajukan kelompok lain. Sedangkan penilaian individu berdasarkan keaktifan dalam proses pembelajaran, kerjasama dalam satu kelompok. Berdasarkan nilai diskusi pada siklus I, siswa yang tidak tuntas ada 5 siswa. Perolehan rata-rata hasil belajar sebesar 62,24 dengan ketuntasan belajar hanya mencapai $78,26 \%$, dengan rincian (terlampir).

Evaluasi dilaksanakan pada tanggal 17 Januari 2018. Pada saat evaluasi semua siswa hadir. Waktu yang digunakan 45 menit untuk menyelesaikan 15 soal pilihan ganda dan 5 soal esay. Siswa yang < KKM dalam menyelesaikan soal evaluasi yaitu 8 anak, nilai tertinggi yaitu 85 dan nilai terendah 30. Dengan perolehan rata-rata hasil belajar sebesar 66,22 dengan ketuntasan belajar hanya mencapai $78,26 \%$, dengan rincian (terlampir).

Dari pengamatan peneliti dan guru selama proses pembelajaran siklus I diperoleh hasil sebagai berikut:

1) Guru kurang menciptakan suasana pembelajaran yang aktif.

2) Guru kurang memotivasi kerjasama sesama siswa, sehingga masih ada sebagian kelompok yang terlihat pasif.

3) Dalam kerja kelompok, siswa yang pandai cenderung mendominasi kelompoknya, sehingga siswa yang lain dalam kelompok tersebut menggantungkan penyelesaian soal diskusi dan presentasi didepan kelas kepada siswa yang pandai, serta kurang adanya kesadaran untuk berusaha menguasai materi.

4) Dalam presentasi dan menjawab pertanyaan di depan kelas masih ragu-ragu, dikarenakan persiapan belajar siswa masih kurang, sehingga hasilnya belum bisa maksimal.

d. Refleksi

Berdasarkan hasil penelitian siklus I, kemudian dilakukan refleksi terhadap langkah-langkah yang telah dilaksanakan. Hasil refleksi tersebut adalah sebagai berikut:

1) Guru diharapkan mampu meningkatkan pemahaman siswa dalam mengelola waktu pembelajaran sehingga diskusi kelompok dan presentasi sesuai waktu yang ditentukan.

2) Untuk mengurangi dominasi siswa yang pandai, maka harus ada pembentukan kelompok baru pada siklus II, serta pengawasan dalam diskusi kelompok kecil sebagai contoh guru memberi pertanyaan diskusi kepada salah satu siswa sehingga ketika siswa ditanya belum bisa menjawab ada motivasi untuk mencari jawaban.

3) Guru diharapkan lebih maksimal dalam membimbing siswa dalam penerapan metode pembelajaran SQ3R sehingga siswa dapat memahami tujuan pembelajaran.

4) Guru diharapkan bisa lebih mengkondisikan siswa yang terlalu ramai. 
5) Guru harus lebih aktif memotivasi dan membimbing siswa untuk melakukan interaksi dalam kelompoknya untuk menyelesaikan pertanyaan diskusi.

6) Hasil belajar siswa belum mencapai indikator yang ditentukan sehingga perlu dilakukan peningkatan aktivitas belajar di siklus II.

2. Siklus II

a. Perencanaan

Pada tahap perencanaan ini, peneliti mempersiapkan segala sesuatu yang diperlukan selama proses penelitian berlangsung, diantaranya yaitu:

1) Menyusun Rencana Pelaksanaan Pembelajaran (RPP).

2) Merencanakan penerapan metode pembelajaran SQ3R.

3) Membuat Pertanyaan diskusi kelompok serta lembar penilaian diskusi.

4) Membuat Soal Evaluasi dan kunci jawabannya, untuk siklus II.

b. Pelaksanaan tindakan

Siklus II dilaksanakan tiga pertemuan, empat jam pelajaran yaitu pada tanggal 20 Januari 2018 dan 24 Februari 2018.

1) Pertemuan pertama (penjelasan materi, \& pembentukan kelompok)

Mengawali siklus II guru mengucapkan salam, memberikan apersepsi dengan pertanyaan proses pencernaaan makanan hingga siswa terarahkan untuk mengingat bahwa zat-zat makanan yang diperlukan dalam tubuh harus sudah mengalami proses yang melibatkan organ pencernaan dan kelenjar pencernaan. Pada siklus II guru menyampaikan peta konsep tentang organ sistem pencernaan manusia. Pembagian kelompok secara heterogen (campuran) yaitu dengan melihat nilai diskusi dan nilai evaluasi siklus I.

Untuk pembagian kelompok dan materi yang diperoleh menggunakan sistem undian tetapi pada saat maju presentasi tidak dapat diacak, misal kelompok 4 maju presentasi didepan kelas lebih dulu karena materi yang harus dipahami dan disampaikan berkesinambungan. Jadi pada saat presentasi kelompok didepan kelas secara urut dari kelompok 1 yang membahas mulut (gigi, lidah), kelompok 2 esofagus, kelompok 3 lambung, kelompok 4 usus halus, dan kelompok 5 membahas kelenjar pencernaan (hati, pankreas, dan kelanjar ludah). Waktu yang digunakan 25 menit diskusi kelompok untuk menyelesaikan pertanyaan diskusi dari peneliti dan membuat rangkuman materi yang akan dipresentasiakan, dan 15 menit waktu untuk presentasi. Setelah semua kelompok selesai presentasi guru menjelaskan secara singkat keseluruhan proses pencernaan, organ yang berperan dari mulut sampai anus serta enzim yang dihasilkan. Macam- macam penyakit sistem pencernaan makanan pada manusia juga diterangkan oleh guru.

Langkah penerapan metode SQ3R dapat dikatakan berhasil atau sudah dipahami dan dikuasai siswa, hal ini ditunjukkan dengan survey atau mencari referensi materi tiap kelompok. Peneliti dan guru tidak menyediakan buku paket tetapi siswa sudah membawa dan mencari buku paket serta referensi dari internet sesuai materi yang diperoleh. Read dan question dalam siklus II selain siswa membaca untuk menyelesaikan pertanyaan diskusi dari peneliti juga mampu membuat dan menjawab pertanyaan dalam diskusi kelompok kecil untuk memprediksi pertanyaan yang mungkin muncul dari kelompok lain saat presentasi.

Presentasi didepan kelas sebagai pelaksanaan ricite dan review sudah mulai tertata dari cara moderator membuka menutup presentasi, menyampaikan materi serta cara membatasi pertanyaan dan menjawab pertanyaan. Penyampaian materi dibagi masing-masing siswa dalam satu kelompok. Pada sikus II pertanyaan yang muncul dari kelompok lain sudah mulai banyak hal ini menunjukan antusias siswa dalam pembelajaran menggunakan metode SQ3R.

Kerjasama dan tanggung jawab siswa sudah mulai terbentuk dengan cara pembagian tugas masingmasing siswa dalam diskusi kelompok kecil maupun presentasi kelompok didepan kelas sehingga tidak ada dominasi satu, dua siswa dalam kelompok serta penguasaan materi yang didapat dalam kelompok. Siswa antusias menyelesaikan pertanyaan diskusi dan mempersiapkan makalah atau rangkuman jawaban pertanyaan. yang akan dipresentasikan sehingga tidak terjadi kegaduhan kecuali saling mempertahankan pendapat dalam diskusi kelompok kecil. Cara guru untuk mengetahui tidak terjadi dominasi penguasaan materi pada salah satu siswa, sesekali guru mengajukan pertanyaan diskusi yang didapat pada salah satu anggota kelompok pada saat diskusi kelompok.

Hasil belajar siklus II terlihat dari nilai diskusi dan nilai evaluasi. Pada saat pelaksanaan pembelajaran mengunakan metode SQ3R sekaligus penilaian diskusi berdasarkan nilai kelompok dan nilai individu. Penilaian diskusi untuk kelompok berdasarkan penguasaan materi yang dipresentasikan, pengelolaan waktu dalam presentasi, pembuatan rangkuman materi sebagai bahan presentasi serta menjawab pertanyaan yang diajukan kelompok lain, kerjasama dalam satu kelompok. Sedangkan penilaian individu berdasarkan keaktifan dalam proses pembelajaran baik mengajukan pertanyaan maupun membantu menjawab pertanyaan apabila presentator tidak mampu menjawab pertnyaan dari kelompok lain, kerjasama dalam satu kelompok. Berdasarkan nilai diskusi pada siklus II, siswa yang tidak tuntas ada 3 anak. Perolehan rata- rata hasil belajar sebesar 75,72 dengan ketuntasan belajar mencapai 91,30\%, dengan rincian (terlampir).

Evaluasi dilaksanakan pada tanggal 27 Januari 2018, pada saat evaluasi semua siswa hadir. Waktu yang digunakan 45 menit untuk menyelesaikan 15 soal pilihan ganda dan 5 soal esay. Siswa yang $<$ KKM 
dalam menyelesaikan soal evaluasi yaitu 2 anak. Dengan perolehan rata-rata hasil belajar sebesar 76,26 dengan ketuntasan belajar mencapai $95,65 \%$, rincian (terlampir).

Berdasarkan hasil penelitian siklus I kemudian dilakukan refleksi terhadap langkah-langkah yang telah diaksanakan. Hasil refleksi tersebut adalah pada pelaksanaan siklus II yang dipandang sudah cukup dalam meningkatkan baik semangat peserta didik, aktivitas belajar maupun hasil belajar siswa pada penerapan "Metode pembelajaran SQ3R dalam materi sistem pencernaan makanan pada manusia untuk meningkatkan hasil belajar siswa kelas XI di SMA Muhammadiyah Aimas sudah mencapai indikator keberhasilan yang ditetapkan".

Pembahasan yang diuraikan disini lebih banyak didasarkan atas hasil pengamatan yang dilanjutkan dengan kegiatan refleksi.

3. Penerapan metode pembelajaran SQ3R

a) Siklus I

Dari pengamatan siklus I diperoleh temuan antara lain guru dalam melaksanakan penerapan "Metode pembelajaran SQ3R" diawali dengan tahap pemberian apersepsi terhadap materi di kelas dengan metode konvensional, kemudian membagi kelompok dan selanjutnya pesera didik melaksanakan proses pembelajaran mengunakan metode SQ3R akan tetapi pengelolaan waktu kegiatan pembelajaran kurang baik terlihat molornya waktu diskusi kelompok kecil sehingga waktu presentasi singkat. Selain itu juga dalam memberikan motivasi dan bimbingan terhadap siswa baik dalam kelompok maupun individu kurang merata sehingga ada beberapa siswa yang merasa kesulitan dalam menyelesaikan pemecahan soal diskusi yang diberikan.

b) Siklus II

Berdasarkan refleksi pada siklus I, pelaksanaan tindakan pada siklus II oleh guru sudah baik dengan bukti pengelolaan waktu yang sudah sesuai dengan rencana pembelajaran dan pemberian semangat oleh guru kepada siswa sudah merata. Disamping itu, siswa juga sudah mampu melaksanakan tahapan-tahapan "Metode pembelajaran SQ3R" dengan baik. Terbukti dengan adanya pencarian referensi yang dilakukan siswa, diskusi kelompok kecil yang berjalan lancar, presentasi yang cukup memuaskan serta mampu menyelesaikan soal evaluasi.

Dari nilai diskusi siswa dalam proses pembelajaran mengunakan metode SQ3R mengalami peningkatan. Hal ini terbukti dengan peningkatan ketuntasan belajar klasikal pada nilai diskusi dari $78,26 \%$ pada siklus I menjadi $91,30 \%$ disiklus II. Serta ketuntasan belajar klasikal pada nilai evalusi dari 78,26 \% pada siklus I menjadi 95,65 \% pada siklus II. Peningkatan ketuntasan belajar nilai diskusi, dengan ketuntasan belajar nilai evaluasi dalam pembelajaran dari siklus I ke siklus II dapat dilihat pada histogram dibawah ini:

Tabel. 4.1. Histogram ketuntasan belajar dari nilai diskusi Siswa dan ketuntasan belajar dari nilai evaluasi siswa

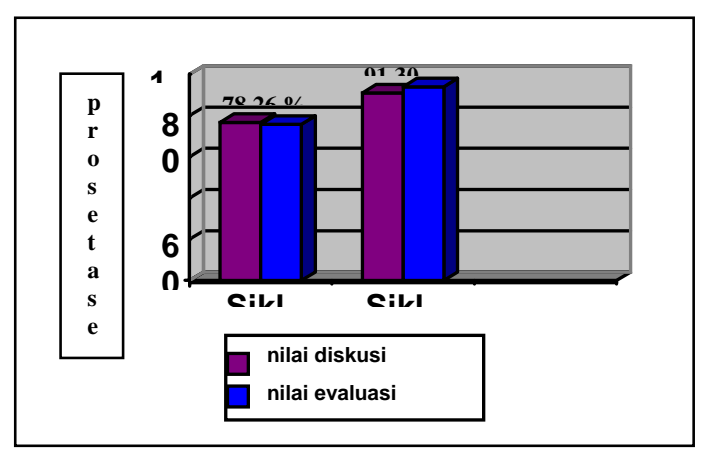

Selain peningkatan yang terjadi terhadap ketuntasan belajar dari nilai diskusi siswa dan ketuntasan belajar dari nilai evaluasi siswa, dalam penelitian ini juga terjadi peningkatan terhadap ratarata hasil belajar siswa. Dengan bukti jika dalam siklis I nilai rata-rata kelas pada nilai diskusi 62,23 pada siklus II mengalami peningkatan yaitu 78,26. Sedangkan nilai rata-rata evaluasi siklus I 66,22 mengalami peningkatan menjadi 76,26. Dapat dituliskan dalam tabel sebagai berikut :

Tabel 4.2. Nilai rata-rata kelas pada nilai diskusi dan nilai evaluasi siklus I dan siklus II

\begin{tabular}{|l|l|l|}
\hline Rata-rata & Siklus I & Siklus II \\
\hline Nilai diskusi & 62,23 & 75,72 \\
\hline Nilai evaluasi & 66,22 & 76,26 \\
\hline
\end{tabular}

Metode pembelajaran

SQ3R lebih mengutamakan keaktifan dan kreatifitas siswa, baik dari mencari sumber/referensi materi, menjawab pertanyaan peneliti yang dihadapkan pada kemampuan memadukan beberapa pemikiran atau argumen dari siswa dalam kelompok, ketelitian membaca serta kreatifitas dalam menyampaikan atau presentasi didepan kelas. Tentunya akan menimbulkan beberapa hambatan apabila siswa tidak mampu diajak kerjasama untuk lebik aktif daripada sekedar menunggu diterangkan guru. Kelebihan penggunaan metode akan menjadi sebuah hambatan tanpa adanya motivasi dari diri siswa dan guru untuk menciptakan suasana kelas yang menyenangkan dan kooperatif.

Hambatan yang terjadi pada siklus I sudah mampu diminimalisir tetapi hambatan yang masih dirasakan dalam siklus II adalah kurangnya sumber bacaan yang tersedia disekolah, motivasi dari siswa untuk belajar masih tergolong rendah apalagi ketika guru tidak mampu bersikap tegas dalam pembelajaran maupun pemberian nilai hal tersebut akan sedikit demi sedikit mengalami perubahan apabila mulai didukung dari berbagai pihak yaitu keluarga dan sekolah.

\section{KESIMPULAN}

Berdasarkan hasil penelitian yang penulis lakukan tentang penerapan metode pembelajaran SQ3R (Survey, Question, Read, Recite, Review) sebagai salah satu upaya dalam meningkatkan hasil belajar pada materi pokok sistem pencernaan manusia di SMA Muhammadiyah Aimas, dapat diambil kesimpulan bahwa:

1. Hasil belajar siswa dengan penerapan metode 
pembelajaran SQ3R (Survey, Question, Read, Recite, Review) khususnya pada materi pokok sistem pencernaan manusia mengalami peningkatan yaitu dari nilai diskusi siklus I dengan rata-rata 62,2 dengan ketuntasan belajar klasikal (seluruh siswa) 76,67\%, meningkat menjadi 75,73 dengan ketuntasan belajar klasikal (seluruh siswa) $90,9 \%$ pada siklus II. Sedangkan nilai evaluasi dengan rata-rata 62,25 dengan ketuntasan belajar klasikal (seluruh siswa) $75,75 \%$ meningkat menjadi 76,30 dengan ketuntasan belajar klasikal (seluruh siswa) 93,93\% . Maksudnya, pada siklus I, ada 7 siswa yang tidak tuntas dalam nilai diskusi serta 8 siswa yang memperoleh nilai evaluasi di bawah KKM (62), sedangkan pada siklus II, hanya ada 3 siswa tidak tuntas nilai diskusi dan 2 siswa yang nilai evaluasinya di bawah KKM.

2. Hambatan yang dialami dalam proses pembelajaran menggunakan metode pembelajaran SQ3R (Survey, Question, Read, Recite, Review) untuk meningkatkan hasil belajar pada materi sistem pencernaan makanan manusia antara lain :

a. Motivasi dari siswa untuk belajar masih tergolong rendah apalagi ketika guru tidak mampu bersikap tegas dalam pembelajaran maupun pemberian nilai hal tersebut akan sedikit demi sedikit mengalami perubahan apabila mulai didukung dari berbagai pihak yaitu keluarga dan sekolah.

b. Adanya keterbatasan buku disekolah, walaupun didukung referensi dari internet, tetapi tanpa adanya kreatifitas siswa untuk mencari sumber materi dari tempat lain, juga akan menjadi hambatan terlaksananya pembelajaran dengan metode SQ3R sehingga hasil belajar tidak mencapai indikator yaitu nilai 62 (sesuai KKM).

\section{DAFTAR PUSTAKA}

Ahmadi , Abu dan Widodo Supriyono (2004). Psikologi Belajar, Jakarta: PT. Rineka Cipta

Almatsier, Sunita (2006). Prinsip Dasar Ilmu Gizi, Jakarta: PT. Gramedia Pustaka Umat.

Aqib, Zaenal, dkk,. (2008). Penelitian Tindakan Kelas untuk Guru SD, SLB, dan TK, Bandung: CV. Yrama Widya.

Aqib, Zaenal, dkk,. (2008). Penelitian Tindakan
Kelas untuk Guru SMP, SMA, SMK, Bandung: CV. Yrama Widya.

Arikunto, Suharsimi (2002). Prosedur Penelitian Suatu Pendekatan Praktek, Jakarta:PT. Rineka Cipta.

Dimyati \& Mudjiono, (2006). Belajar dan pembelajaran, Jakarta: Rineka Cipta.

Harsanto, Ratno (2007). Pengelolaan Kelas Yang Dinamis, Yogyakarta: Kanisius.

Irianto, Kus. (2004). Struktur dan Fungsi Tubuh Manusia Untuk Paramedis, Banndung: Yrama Widya.

Kemmis \& Mc. Taggart (2010). The Action Research Planner. Geelong: Deaken Univercity Press.

Kurniasari, Nita, (2007). Penggunaan Metode Survey, Question, Read, Recite, Review, (SQ3R) Dalam Pembelajaran Kooperatif Untuk Meningkatkan Hasil Belajar Ekonomi Pokok Bahasan Sistem Perekonomian Indonesia Pada Siswa Kelas VIII SMP NU 01 Muallimin Weleri Tahun Pelajaran 2006/2007, Penilaian Fakultas MIPA UNNES, Semarang: Perpustakaan UNNES.

Mushobikhatun (2008). Keefektifan Metode SQ3R Pada Pembelajaran Konsep Sistem Ekskresi Di Madrasah Aliyah Al Asror Gunungpati Semarang, Penilaian Fakultas MIPA UNNES, Semarang: Perpustakaan UNNES.

Zuriah, Nurul (2006). Metodologi Penelitian Sosial dan Pendidikan Teori-Aplikasi, Jakarta: PT. Bumi Aksara.

Sagala, Syaiful (2003). Konsep dan makna Pembelajaran, Bandung: CV Alfabeta.

Sanjaya, Wina (2009). Strategi Pembelajaran Berorientasi Standar Proses Pendidikan, Jakarta: Kencana Prenada Media Group,.

Skinner, Charles E.( 1958). Essentials Of Educational Psychology, Tokyo: Maruzen Company.

Sudjana, Nana (1999). Penilaian Hasil Proses Belajar Mengajar, Bandung: PT. Remaja Rosdakarya.

Syah, Muhibin (2000). Psikologi Pendidikan Dengan Pendekatan Baru, Bandung: PT Remaja Rosdakarya.

Yamin, Martinis, dkk (2009). Manajemen Pembelajaran Kelas, Jakarta: Gaung Persada. 